\title{
The Institutionalisation of Political Science in ECE: The Grounding of Theory
}

\author{
Gabriella Ilonszki
}

\section{INTRODUCTION}

The goal of this chapter is to establish a theoretical framework regarding the institutionalisation of political science as an academic discipline, by building on the experiences of 16 selected countries. There is substantial literature dealing with the question of institutionalisation, but the concept itself is rarely defined, or it is used in a loose manner with regard to how a discipline becomes established. The present chapter tries to rectify this not only by creating the aforesaid theoretical framework but also by linking it to concrete evidence from the selected latecomer and/or peripheral political science communities. A common theoretical frame, sound evidencebased research, and a comparative approach will hopefully contribute to the literature on the institutionalisation of our profession. Furthermore, while the question in itself of how this academic field is being developed is a challenging one, our focus might provide some insight into the institutionalisation of disciplines in general.

G. Ilonszki $(\bowtie)$

Department of Political Science, Corvinus University of Budapest, Budapest, Hungary

e-mail: gabriella.ilonszki@uni-corvinus.hu

(C) The Author(s) 2022

G. Ilonszki, C. Roux (eds.), Opportunities and Challenges for New

and Peripheral Political Science Communities, https://doi.org/10.1007/978-3-030-79054-7_2 
The country case selection is justified on several grounds, as explained in Chap. 1. Within this group, in the large majority of cases, political science only became an established discipline in the 1990s. However, it does not necessarily follow that they followed identical pre- or postdemocratisation paths, and thus similar patterns of institutionalisation of the discipline. In some countries, political science had been established to some extent during the communist period (Croatia and Poland). Other countries are still struggling to establish the profession (Belarus and Moldova), while others still, due to their size and geographically remote position, are rightly classified as 'latecomers' as well, even though they seem to be following West European patterns with regard to the development of the discipline (Malta and Iceland). These differences within the selected group of cases represent an important comparative asset. Also, the performance and academic visibility of these countries still lags behind that of the 'older' cases, which contributes to the problem of institutionalisation: what brings success and what accounts for and aids performance? Does the latecomer and/or peripheral status of such countries itself provide an explanation?

There are three clearly defined problem areas concerning the state of political science in these countries that go beyond their geographical location and exacerbate the problem of the discipline's institutionalisation. These are the problems of catching up, integration and relevance.

The first one speaks for itself: how can the latecomers catch up with the Western forerunners? From an internal point of view, this is what Hankiss has called the 'catching up neurosis' (Hankiss, 2002, p. 19), that is, the question of whether these countries are ready to offer proper political science on the basis of what they have. From an external perspective, the problem seemed a more practical one. While Klingemann (2008) argued that '.. after the breakdown of Communist regimes, Central and Eastern Europe is catching up' (Klingemann, 2008, p. 389), he also admitted that 'more information is needed about the institutionalization of political science in Central and Eastern Europe' (Klingemann, 2008, p. 379; see also Klingemann et al., 2002). It is commonly understood that political science is a science of democracy, in the sense that democracy is both a required framework for, and the focus of attention of, political science. As Easton et al. (1995) argue: 'political science does exist in non-democracies, but their nature has been transparently different' (p. 3). Nevertheless, can the democratic requisite account for the success or failure of the profession in real terms? Thirty years after the democratic breakthrough in many 
formerly communist countries, it seems that the initial creation and growth of the profession have not been accompanied by a similar degree of institutionalisation, and thus will not automatically lead to the discipline catching up with that in other Western countries. Both systemic aspects-that is, the state of democracy-and pragmatic aspects-like the availability of human and financial resources - can be considered to provide an answer to the first question.

Secondly, how can the latecomer and/or peripheral political science communities be integrated into the more established ones? Catching up and integration are two distinct phenomena and as such need to be examined separately. Catching up focuses on the comparative aspect, that is, on whether levelling prevails in the process of institutionalisation; integration, on the other hand, refers to how patterns of cooperation develop. Naturally, the two concepts are interconnected, as internationalisation and partnership require equal standing of those involved. Nevertheless, even within Western Europe, political science is not integrated fully: common standards prevail in regard to certain key aspects, particularly professional training and education, while differences continue to exist in terms of performance, visibility and resources (Meny, 2010). We would expect this to be true of our selected country group. It is easier, and even required by EU policy governing EU member states, to develop common standards in training and education; other aspects of integration, however, depend on more nuanced opportunities arising at the country level (Pleşu, 2002).

Finally, how relevant is political science in the countries under consideration? It could be said that the issue of relevance has been a persistent problem for political science since it first appeared as an accepted academic discipline in educational institutions; in other words, there has always been this problem of how to talk about and explain politics while not acting as a demagogue or prophet (Weber, 1918). In more recent times, the main question became that of how to be a useful, practice-oriented profession capable of going beyond the mere promotion of 'good citizenship and better government' (Ricci, 1984, p. 70). This issue emerged more forcefully when external demands began to increase. Educational managers, policy-makers and politicians want returns for 'their' investment, and as such they tend to dispute the relevance of political science. The political science profession in the West repeatedly put forward requirements for a relevant science capable of addressing a broad audience, of ensuring quality performance, of promoting civic culture, and of connecting research to the extra-educational realm (for a conclusive summary, see Stoker et al., 
2018). These relevance requirements presuppose a well-established, properly functioning, resourceful science. How can relevance be acquired by the members of the latecomer country group?

Initially, with the process of democratisation, it seemed that political science automatically and immediately became relevant; that is, it could talk to people and they could listen to it. However, a 'bottleneck' soon appeared. While politicians in general do not like to hear the truth, during the pre-democratic period, this was even more so, and consequently, practice-oriented research and education were not well developed. Moreover, in some new democracies, political scientists tend to refrain from any engagement with politics as a result of former negative experiences. At the same time, institutional constraints on academia increase in the latecomer country group as well, and the 'expectation gap' (Flinders, 2018 ) widens here too. Overall, while this debate mostly appears within a 'Western context', it has similar implications in our selected country group. The way in which different patterns in this regard develop remains to be seen.

With these three main issues forming the background, in the following sections, we shall first establish the institutionalisation concept supporting the comparative approach adopted in the book, followed by the suggested institutionalisation frame. In the last section, we shall discuss the potential implications of this framework for the institutionalisation of the East Central European (ECE) country group.

\section{Approaching the Institutionalisation Concept}

This section will introduce the major definitional issues that frame the concept of the institutionalisation of political science. Whether a discipline is institutionalised revolves around three issues: the process, that is, how institutionalisation develops; the outcome, that is, which properties appear indispensable if a discipline is to be institutionalised; and lastly, what contextual factors are essential in influencing either process or property. After presenting the dilemma of the concept of institutionalisation itself, we shall then outline its context-driven substance.

\subsection{The Dilemma: Process and Property}

The dilemma of concept building is that it is not enough to define an outcome demonstrating that a discipline has been institutionalised, as the 
process of institutionalisation has equal value in understanding whether the discipline is institutionalised or not. The two cannot be separated: the processes will lead to certain institutional outcomes that we call properties, while the outcome will have an impact on how the process continues, as institutionalisation is constant (Peters, 1999, p. 67). Even a settled, well-functioning discipline needs to respond and adapt to new challenges, and thus, the process leading to a certain outcome should and would continue. For example, we can argue that institutional stability is necessary for a discipline to function properly, but stability is not a static property and thus the process of adaptation will continue in order to achieve a renewed, transformed stability. The process resulting in this institutionalised outcome and regularly shaping it becomes part of the concept: the process of institutionalisation and the outcome of this process are closely intertwined, and inform us of the institutionalised nature of a profession.

Paradoxically, while institutionalisation is a widely used concept, it is nevertheless not easy to grasp. As DiMaggio \& Powell observe (1991) 'scholars who have written about institutions have often been rather casual about defining them; institutionalism has disparate meanings in different disciplines' (p. 1). This vagueness is not accidental: it is not only due to the presence of several schools in the field but also due to the complex nature of the concept. The institutionalisation of a discipline requires similar and different analytical approaches as the 'general' concept of institutionalisation (DiMaggio \& Powell, 1983); therefore, we should adopt here the general concept flexibly. We are going to follow a deductive approach based on a critical review of the literature (Brady, 2001; DiMaggio \& Powell, 1983; Eisenstadt, 1968; March \& Olsen, 1984; North, 1991; Pierson, 2000; Peters \& Pierre, 1998; DiMaggio \& Powell, 1991).

Despite the complexity of the concept, a review of the literature shall enable us to establish which features - we shall call them properties-are indispensable for a settled, duly functioning discipline, and which institutionalisation properties are required if political science is to be considered institutionalised. In view of the relevant literature, we have selected those properties that embody institutional outcomes that are essential if the profession is to enjoy a healthy existence. As for the relevant, indispensable institutional outcomes, the properties of stability, identity, autonomy, reproduction and legitimacy have been defined and will be introduced in detail in Sect. 2.3. These are the features that embody a well-institutionalised science: one that should have stable existential patterns, a clear academic identity and profile; one that should be able to independently define its 
own rules and norms while getting external agents to accept them, and be able to ensure its own reproduction and to establish and maintain a legitimate position in the smaller or larger outside world.

As mentioned above, the same properties of institutionalisation can have different connotations in different subject matters. This does not exclude them from the 'property list', but simply signifies that although institutionalisation theories can be applied throughout different subject matters, the measurement and implications of the properties may operate differently. For example: Huntington (1965), writing on political development, mentioned stability as a property which makes a political system well-institutionalised. In keeping with other writings, we shall also regard stability as a property of institutionalised political science. Without this feature, it is difficult to imagine that this field of science (or indeed any science) can accommodate and adjust to diverse external challenges and can envisage valid prospects for the future. Nevertheless, while Huntington claims that the more complicated the organisation, the more highly institutionalised it is, that is 'complexity produces stability', from the perspective of our science this is not necessarily the case. More complexity might be a source of fragmentation-as when new subfields within the field of political science (such as international relations, gender studies or methods) eventually aim to establish their own separate institutional framework (departments, research centres, programmes, etc.) and thus challenge the original stability.

Paradoxically, while institutionalisation properties seem to be constant, in the sense that they are recurrently mentioned and accepted by the institutionalisation literature irrespective of their subject matter, they bear a powerful degree of internal dynamism. The dynamism of the concept emerges in the connection between institutionalisation properties and the process of institutionalisation. The process qualifies institutionalisation while being part of it. For example, whether the institutionalisation process is incremental or occurs as a breakthrough, is top down or bottom up, whether there are many or few actors involved in the process-and ultimately who they are-will all be decisive aspects of institutionalisation and will add to the property itself. Using the 'stability' example once again: under the assumption that for the purposes of stability, dynamic adjustment potentials are inevitable and incremental changes tend to promote adaptive steps, it seems important to establish whether the process represents a breakthrough or is one of incremental change. Political science institutions may be more stable and more resilient if they are the result of 
a number of adaptive steps in a longer process. The process, even if not as enjoyable as March \& Olsen claim (1984, p. 741), is certainly at least as fundamental as the property itself to an understanding of the institutionalised nature of a profession. The process and the property are difficult to completely separate. In connecting the institutionalisation process with given institutionalised positions, the difficulty lies in the fact that both are dynamic: the former genuinely so and the latter due to its inherently composite nature.

Even a well-institutionalised science has to adapt due to internal and external demands and requirements; that is, it constantly changes in response to new challenges. These new challenges will trigger the transformation of the institutionalised framework. This process can be described as a series of discrete events or as a continuum of learning and adaptation; the way in which the process is more easily grasped is once again telling about institutionalisation. This mirrors Peters' approach (1999), according to which: 'In some ways the process of institutionalisation appears to be a two-step process. First, there must be some conscious decision to create an organization or institution for a specific purpose. The second stage appears to be then to fashion the institution over time' (Peters, 1999, pp. 32-33). A few fundamental changes could imply different institutionalisation patterns and outcome from those produced by several incremental changes developing along a continuum. Indeed, the process often seems to be more interesting and more important to an understanding of institutionalisation than the outcome itself. In addition to the institutionalisation dilemma, that is, the delicate and complex relationship between process and property, there is also a third question, namely that of whether context is of functional importance to the formation of an institutionalised discipline. In other words, whether context impacts the process of institutionalisation and the development of properties.

\subsection{The Context: Structures, Norms and Agents}

The second set of conceptual questions concerns the fundamental rationale of institutionalisation: why does it happen in the way it does and what contextual factors we should consider as explanations for its occurrence? The assumption that institutional change and transformation, and institutionalisation per se, can be explained in functional terms, and that it represents a straightforward, one-way process, falls short of reality. In principle, institutions are created to fulfil certain goals; however, new 
aspects could well trigger a re-interpretation of how to achieve a goal, due to the transformation of the context. An example could be how one of the profession's fundamental goals, that of establishing a clear identity for itself and thus making the profession visible, can be re-interpreted as a new context takes shape following the restructuring of universities for financial reasons or in consideration of other policy goals. The aim of establishing separate political science departments might be given up if identity can be ensured by means other than that of exclusive, functionally separate academic units. This example illustrates how context offers an adaptive interpretation that goes beyond a direct functional approach (Pierson, 2000). Rather, the complex consideration of structures, norms and agents-as context-may account for institutional change.

The profession itself can be rightly regarded as a context which influences its own institutionalisation as such. According to the typology formulated by Hodgson (2006), science is particularly agent sensitive, and we can rightly assume that political science, with its ethos-prone, self-reflective attitudes, is a clear case of an agent-sensitive science. Political science literature has identified several other features of the profession which may have an effect on its institutionalisation, namely the rural quality of political science (the small number of agents and organisations); its nature as a soft science (having no strict scientific method); its pure science features (having no practical application); and its divergent/variegated character (its unclear specific identity; Becher \& Trowler, 2001; Capano \& Verzichelli, 2016). This approach, however, deserves further consideration. For one, these specificities change over time: in the past 20 years or so, the number of political science schools, students and academic staff has increased, although the country group under consideration here is varied in this regard: time period differences and country differences can be observed within this group. Moreover, the discipline's development in terms of its methodological skills and its practice-oriented focus would appear to challenge some of the aforementioned features of the political science profession.

At the same time, in other respects, the nature of the profession does indeed matter and has implications on its institutionalisation: in particular, political science's 'inception conditions', that is its connectedness to democracy and its strong ethos. On these grounds, political science is more exposed to changing context than most other academic fields. In the more established, 'older' political science communities, the ethos debate seems to accompany the relevance debate mentioned above: that is, the 
question of establishing the tasks of our science, and how it can perform new tasks. The institutionalisation of political science is affected by context due to its openness, and to some degree vulnerability, to the broad societal-political context. Only in extreme cases can we imagine that a linguist or an art historian will be affected by the "expectations" of decision-makers or their political clientele. This is not true of political science, where such expectations are important, and in new democracies, political change or democracy deficits could have consequences for its institutionalisation potential.

Finally, time is an important, complex aspect when trying to understand institutionalisation, not only in the sense described above (when does institutionalisation start) but also with regard to the length of certain momentums and how these are situated and structured in and over time. This leads us back to the understanding of institutionalisation as a process. The triggering events, the incremental or fundamental changes, that have defined the development of political science, should be clearly set out. Situating these steps in time will provide information about institutionalisation and will be a cure for the problem of circularity, a frequently raised criticism of institutionalisation theory (Peters \& Pierre, 1998). Connecting changes (including types of changes) to time will mean that causal explanations of institutionalisation will be clear, and causal sequences can be introduced. Otherwise, with no clear time perspective, the process of institutionalisation will remain blurred, while causes, consequences and corrective steps will remain unidentified, and consequently, it will be impossible to properly assess the state of institutionalisation.

In addition to the profession itself and the time frame, a large number of external conditions influence the institutionalisation of professions. These external conditions are the institutions themselves, not only structures or organisational units, but also norms, procedures and behaviour (North, 1991). Ranging from legal provisions to the organisation of higher education, diverse structures determine the developmental route of a discipline; however, these are built on norms and rules, and their interconnections cannot be distinguished. The structures are established by different actors who interpret structural transformation and norms as well, since 'Human actions, social contexts, and institutions work upon each other in complicated ways' (March \& Olsen, 1984, p. 742). To reiterate the starting point of this section: this is context per se. 


\section{Institutionalisation-Properties, Indicators AND MeAsures}

As explained in the above sections, institutionalisation is achieved in the form of certain outcomes/properties. Table 2.1 illustrates this framework in the form of the five properties based on a review of the literature, namely stability, identity, autonomy, reproduction and legitimacy. The table then presents the indicators of the existence of said properties, followed by the measures by which the relevance/degree/presence/absence of the indicator can be demonstrated. These indicators define the institutionalisation properties in their ideal forms, while the measures reveal the advancement of said indicators. Potentially, this framework can help

Table 2.1 Properties and indicators of institutionalisation

\begin{tabular}{|c|c|c|c|}
\hline No. & $\begin{array}{l}\text { Institutionalisation } \\
\text { property }\end{array}$ & Indicator & Possible Measures \\
\hline 1 & Stability & $\begin{array}{l}\text { Durability } \\
\text { Attendance } \\
\text { Adaptation }\end{array}$ & $\begin{array}{l}\text { The institution's lifetime } \\
\text { No. of students (steady/fluctuating/ } \\
\text { declining) } \\
\text { No. of institutions (steady/ } \\
\text { fluctuating/declining) } \\
\text { Frequency of structural reforms }\end{array}$ \\
\hline 2 & Identity & $\begin{array}{l}\text { Differentiation } \\
\text { Collective action } \\
\text { Visibility }\end{array}$ & $\begin{array}{l}\text { Distinct from other disciplines; } \\
\text { separate PS institutions/ } \\
\text { programmes; established associations; } \\
\text { media presence; local and } \\
\text { international conference attendance }\end{array}$ \\
\hline 3 & Autonomy & $\begin{array}{l}\text { Decisional } \\
\text { independence } \\
\text { Evaluation } \\
\text { Funding }\end{array}$ & $\begin{array}{l}\text { With regard to hiring and promotion } \\
\text { and establishing subfields and } \\
\text { research fields; standardised } \\
\text { evaluation; set and transparent } \\
\text { sources }\end{array}$ \\
\hline 4 & Reproduction & $\begin{array}{l}\text { Reproduction at } \\
\text { the national level } \\
\text { Professionalisation } \\
\text { International } \\
\text { integration }\end{array}$ & $\begin{array}{l}\text { Staff composition; PhD training; } \\
\text { institutional homogeneity in working } \\
\text { rules and norms; use of English in } \\
\text { teaching; thematic connectedness; } \\
\text { joint research and publication }\end{array}$ \\
\hline 5 & Legitimacy & $\begin{array}{l}\text { Performance } \\
\text { Influence } \\
\text { External } \\
\text { recognition }\end{array}$ & $\begin{array}{l}\text { Cumulated academic } \\
\text { impact; publishing; advisory capacity; } \\
\text { objective recognition by main } \\
\text { customers }\end{array}$ \\
\hline
\end{tabular}

Source: Author's own framework. Thanks to V. Anghel for her initial input 
describe real cases and make comparisons possible either between cases or in regard to one case at different periods of time.

Below, we briefly introduce the question of how to apply the properties and the indicators for the purposes of analysis.

\subsection{Stability}

Stability is a crucial property: stability and how stability is acquired and maintained are essential, as without stable patterns it is impossible to work out adaptation strategies, prospects are uncertain, and uncertainty can undermine the healthy working of the discipline. Only a stable framework can ensure that those inside feel safe, that prospects are visible, and that the necessary adaptive steps can be considered. Stability does not imply a rigid, unchanging framework, however. Uncertainty-whether political uncertainty at the systemic level or simply a shortage of information about the policy and structural changes that impact the profession's prospectsundermines stability and affects the entire institutionalisation process. Stability cannot be expected or guaranteed if the agents concerned are uncertain about the time frame of their planned setup or if the new setup can be easily changed by external actors (Pierson, 2000).

Stability is dynamic, has an inherent liveliness and contains a constant process of adaptation to new challenges. If the profession fails to adapt and to respond to new demands, then its institutionalised character will be threatened. This also implies that a mere collection of static data will not provide a correct picture of how stable or institutionalised the profession is. The measures should be dynamic and should be interpreted comparatively. For example, in a small country where there is no room for a large number of educational units or PhD programmes, if political science's academic reproduction remains safe and is not challenged by imponderable changes, then the field can be rightly regarded as institutionalised. While size and growth are often regarded as fundamental components of institutionalisation (Becher \& Trowler, 2001, p. 14), they do not equate to it.

There are a number of measures that can be used to demonstrate whether stability has been achieved. These include the lifetime of institutions, the frequency of structural reform in higher education, and in particular, the impact of such reform on the existence of political science as an academic discipline. Within this framework, the transformation of the university per se can be a measure of stability: that is, a measure of whether it 
promotes the stability of political science in academia at all. The stability or fluctuation of student numbers will also affect stability. We should bear in mind, however, that these measures are not always independent variables, as will be the case with other measures as well. For example, student numbers are not simply a question of demographics: they can be promoted/curtailed by tuition fee policies, by the comparative advantages/ disadvantages of other academic subjects and the aura surrounding the profession itself. This confirms our observation regarding the importance of time to our understanding of the profession's level of institutionalisation: it is important to establish whether student numbers fluctuate due to demographics (in which case corrective measures can be introduced, and consequently, the stability and institutionalised nature of the profession would persist) or due to unfavourable, or even unpredictable, policies that appear to threaten institutionalisation.

\subsection{Identity}

Regarding the profession's identity, the basic expectation is that the distinctiveness of the profession be established in organisational, academic and personal terms. From the organisational perspective, this would require academic units that are visible and distinct from adjacent disciplines, or political science associations that are based on the norms of the profession and are able to demonstrate its identity. Identity will elevate the prestige of the discipline and will promote its further progress. Academic identity will also contribute to the self-esteem of the insiders, that is, of political scientists themselves. Group identity would give the discipline and the persons involved a higher status (Larson, 2018).

Nevertheless, as a previously mentioned example shows, distinctiveness can be achieved through diverse measures and not only by means of separate organisational units. The process of identity formation does not exclude cooperation with other disciplines. On the contrary, very often, patterns of cooperation are clear signs that a particular discipline is needed and acknowledged by other fields. In a changing environment where new competitors or shrinking resources at university level arise, the profession's identity itself will change. Careful consideration is required, however, to establish whether fundamental aspects of the profession's focus, goals and performance have remained intact. A number of quantitative indicators can be used as measures: what patterns are there in separation from, or cooperation with, other social sciences; how do political science 
associations operate; and how can the visibility of the profession be improved and how can it be more easily identifiable for a broader audience? These measures-indeed these questions - arise strongly in the case of most latecomer political science communities: in some places, political science has been established from scratch, separate from other academic units; in other places, it has formed within, or connected to, an established academic discipline; and in others, it has taken the place of former ideologically loaded university units. These different starting points could have had an impact on identity formation, since despite the longer timeframe, the conditions for the discipline's formation have a lasting impact on the identity of the profession even in the by now established political science communities.

Of the aforementioned indicators, national associations have a special role to play in identity formation as they can establish a common ethos and communality. Nevertheless, occasionally a profession does not take advantage of this potential for collective action. The reason for this could be their small size together with individual competitive strategies having a potentially negative impact on identity formation or the dividedness of the community, which again might be a cause for concern in newly democratising countries. The country differences will illustrate how political scientists value potential collective action, and can see the advantages in promoting the status of the profession in this way. Furthermore, the identity of the national association may tell us something about the identity of the profession itself: is it exclusively an organisation for political scientists as such, or does it include supporters and interested agents, like journalists or members of other professions? These types of difference provide an indication of the profession's identity ambitions, although these ambitions may change over time. It should come as no surprise that our country group is characterised by a large range of diverse associations, due to the recent formation and (re)-interpretation of political science's professional identity. The combination of norms, agents and structures jointly influences institutionalisation in terms of this particular property as well.

\subsection{Autonomy}

Autonomy as a property of institutionalisation is possibly the most difficult to operationalise, since the ideal of independence in important aspects of the profession's functioning is fundamentally curtailed by external agents and the context in general. 
Ideally, autonomy means that the profession can independently decide to establish its own fields of research, to incorporate new subfields into a given academic unit, and to have a say in promotion and hiring procedures. Overall, the profession should have influence over, and be able to work out, standards governing its own institutional and individual functioning. While the measures seem to be obvious and identifiable, the implementation and functioning of this institutionalisation property is highly controversial. On the one hand, the rules governing the operation of an academic discipline have become less personalised, and clear patterns have been recently established; this process has contributed to the institutionalisation of the discipline, with personal decisions and personal dependencies having been replaced by set patterns. This clearly outlined self-government, on the other hand, has been fundamentally influenced, although not formally curtailed, by the transformation of universities as such. Universities have become increasingly dependent on external stakeholders, and these stakeholders have different ideas and preferences regarding institutional performance, expediency and efficiency (Aarrevaara \& Dobson, 2013). This impacts funding, which is one aspect of autonomy: without clear, secure funding, neither education nor research can flourish. The transformation of the university system started back in the 1960s and was accelerated by the advent of mass higher education. Many years ago, Wilensky (1964) pointed out that in order to preserve the autonomy of universities, their governance should remain in the hands of scientists-although he made no mention at the time of the (dysfunctional) role of managers in university governance-and that the scientists themselves should be in a strong market position. The situation is a paradoxical one: while the decisional independence of the profession, and in wealthier countries its healthy funding seem to prevail, even large entities are struggling to preserve their autonomy. These problems are clearly visible in the case of several new academic communities: the role of private institutions was particularly problematic following the democratic transition; a shortage of funding remains an issue everywhere and is often characterised by declining trends; and evaluation requirements are becoming more stringent despite the unfavourable conditions or are being established without the say of the academic community in several countries. 


\subsection{Reproduction}

The reproduction of a discipline and the indicators regarding this property, as with institutionalisation properties, consist of organisational and individual aspects, both of which call for a certain homogeneity, otherwise the profession's reproduction will be of an uneven character. Organisational theory claims that institutionalisation necessarily points to homogenisation: in the initial stages of their life cycle, organisational fields display considerable diversity, but as an institution becomes gradually established, homogenisation follows (DiMaggio \& Powell, 1983, pp. 148 ff.): the constituting units assume similar forms, as the same claims, tasks, ambitions and requirements drive them in the direction of isomorphism. Homogeneity will ensure similar standards in working conditions and other opportunity structures.

Thus, we would argue that a well-spread and organisationally homogeneous discipline will contribute to the healthy reproduction of both the organisational units and their personnel. The academic field is strengthened if the various institutions are competitive. A good number of academic units (this number of course depends on the size of the country) — offering similar quality and thus being equally attractive to different potential audiences-will ensure the homogeneity of reproduction. The profession's organisational and personal homogeneity are intertwined, and they both sustain the reproduction of the profession. For example, a fairly well-institutionalised profession should produce a sufficient number and quality of staff spread evenly across the different institutions concerned.

Overall, on the basis of several developments ranging from global science to the Bologna process, the spread of mass education and globalisation, the expectation is that institutionalisation would point to homogeneity. However, both the broad international academic literature and reports on the state of the discipline in some more recent political science communities, express concerns in this regard (Kwiek, 2016). Homogenisation seemed more evident a generation ago, when institutional development 'followed a snakelike process' with lower-ranking institutions following the higher ranking ones, just as a snake's body follows its head. From the 1980s onwards, however, institutional diversification became the dominant trend (Becher \& Trowler, 2001); several institutions have not followed the pattern of those leading the way, and this may well imply academic quality concerns in terms of the reproduction of the profession. We have reason to believe that in the country group 
examined here, similar problems prevail (Ghica, 2014). The proliferation of new institutions, particularly during the early years of democratisation, has not resulted in the homogeneity of institutions. More recently, decreasing funding and interest in a number of countries has exacerbated the problem of uneven organisational development, which undermines not only the reproduction of the discipline but also its institutionalisation as such.

Reproduction should also prevail in individual terms. If, for any reason, personnel reproduction is not guaranteed, then this could threaten the institutionalisation of the profession. The number of staff and their attributes, career patterns, PhDs and fields of activity, can act as a measure of the processes of reproduction in this regard. This individual component of reproduction is a sensitive issue in most of the countries examined in the following chapters, and it relates to how this academic field can professionalise; that is, how a stable body of members can be established within the profession's working norms. The patterns of reproduction of personnel are often mixed in these countries. This may be the result of generational change, which is consequential both for reproduction and homogenisation, and seems to be particularly relevant in the selected group of countries considered here. A new generation with a sound education and different experiences will possibly offer different answers to the various aspects of institutionalisation than those offered by previous generations; they will possibly perceive the profession differently and show that institutionalisation requires the past to be forgotten for good (Pierson, 2000). At the same time, the reproduction of personnel is often problematic in some countries, where insufficient opportunities within the country force individuals to emigrate in search of employment. In the absence of either institutional or personal reproduction, the political science profession as such will be under threat.

\subsection{Legitimacy}

Legitimacy can be regarded as the most complex property of institutionalisation and is the one with the most pronounced external component: the justification for, and general acceptance of, the discipline is constructed externally and will peak in its legitimation. While it is not the last stage of institutionalisation as understood in the everyday use of the word, given that the properties of institutionalisation are not arranged in a hierarchical 
order, nevertheless when legitimacy is achieved this implies that the profession is fully acknowledged by all the major actors concerned.

This framework includes formal/legal recognition, public recognition and recognition by the decision-makers. When the legal/formal opportunities are provided, the public recognises the profession as a result of its performance and availability, and the decision-makers acknowledge this by providing favourable conditions, then political science as a profession can be considered to have achieved legitimacy. In other words, when there is no longer any questioning of whether the profession is necessary or not, then it can be regarded as legitimate.

Despite this seemingly 'easy' definition and measurement, it does not follow that legitimacy is uniform. It might well be that different external actors hold different views: an important clientele, namely the student body, might have more favourable views than government decisionmakers. The interaction of the different actors and the coming together of their diverse perspectives will establish different legitimacy patterns. In return, the response of the profession in terms of type of performance and type of influence it will favour, will impact its legitimate standing.

We should recognise the fact that indicators are not irremovably separated, and occasionally some of their measures coalesce. For example, collective action is defined as one indicator of the profession's identity, and the national association of political scientists may be used as a measure of such collective action. At the same time, the professionalisation of the discipline appears to be an indicator of performance, suggesting (among other things) that the profession's working rules be taken as a measure of said professionalisation. Clearly, a properly functioning national association should also serve as a measure of the discipline's degree of professionalisation, given that it formulates the norms and rules of professionalisation. We expect that despite the occasional complexity, the general framework demonstrates the possible processes leading to institutionalisation. We intended to apply a measure just once in the framework, even though a more substantial (and lengthier) qualitative analysis may prove that the same measure can function either directly or indirectly. For example, funding is a direct measure of autonomy, since financial support (if guaranteed) ensures the autonomy of the profession. At the same time, funding may also appear as an indirect measure of external recognition, and recognition will likely influence the conditions of the profession's foundation. All of this shows that there is plenty of room for the further development of the suggested framework. More specifically, the measures 
shown in the table could be broadened so as to make the framework more explicit. The country chapters in the volume will certainly broaden this perspective and will establish a basis for a further, more extensive and more complex institutionalisation framework for our profession.

\section{Theory and the Selected Country Cases}

In the previous sections, the potential relevance of the problem of institutionalisation to the selected country group has been repeatedly mentioned, and institutionalisation has been problematised bearing in mind the specific conditions of the countries in question. This section will go a step further and put forward some specificities that may require consideration in order to fully understand institutionalisation and the state of the discipline. Formation conditions, potential starting points, stability concerns and the issue of "regionality" should all be specifically considered.

Thirty years after the process of democratisation began, observing the state of the discipline in the selected ECE country group, it might be worth considering whether the conditions under which the discipline was established in those countries are still valid. DiMaggio and Powell (1983) claim that institutionalisation occurs in three manners. Firstly, it can be coercive, when external actors, often in the form of the State, require the creation or transformation of certain institutions. Secondly, institutionalisation can be built on normative grounds, when the main aim is to settle norms and rules. In this case, the momentum often comes from insiders. Finally, institutionalisation can be mimetic, that is, it may consist in copying, in an attempt to follow apparently useful and advantageous former institutional structures and practices. These three ways in which institutionalisation is achieved are arguably present, in a complex way, in all aspects of institutionalisation. What function do these options have in the selected country group, and how do they possibly reflect the state of the discipline? The formation, and subsequently the development, of the discipline is likely structured by the triggers of this process.

External pressures are not necessarily related to actual actors: major shocks or crises can challenge the existing framework and encourage a new institutional setup, and such shocks can bring about positive outcomes. With regard to political science as a discipline, systemic change could be considered to be a positive shock that brought about opportunities to establish political science as an academic discipline. This external shock was a trigger and opportunity for the foundation of the new academic 
discipline. Thus, it can be argued that in the main, mimetic changes were the ones that impacted the formation of the discipline. Although there might be country differences in this regard, depending on the existence of a preparatory phase prior to the democratic 'shock', or on the presence of institutional entrepreneurs capable of actively influencing the process, mimetic changes can be widely expected. In contrast, institutionalisation generated from inside, when the very participants and agents formulate institutionalisation demands, often in order to establish norms and rules, was possibly a rare occurrence. The understanding of these two types of pressure and their corresponding strength, remains an issue in the unfolding of the institutionalisation of political science in these countries. Are mimetic changes still decisive, and if so, how have they influenced-if at all-the developmental trends of these countries ever since? And even more importantly: what has structured more recent developments and the institutionalisation process itself? Indeed, this latter question augments our framework: we can duly expect a more institutionalised discipline if the internal actors 'take over'. This is not simply an addendum to the autonomy of institutionalisation, since it refers to, and covers, the entire logic of the development of the discipline, that is, the route it intends to follow.

As for the formation issue, in addition to the type of change (mimetic or internally driven), the relevance of the starting point is also important. 'The process of institutionalisation always takes off from several fixed starting points ... and from the concrete organizational structures in the preceding situation' (Eisenstadt, 1968, p. 415). Careful consideration needs to be given to what can be regarded as the decisive starting point. We need to identify those episodes and processes whose consequences persist and continue to influence the institutionalisation of our time (Peters, 1999, p. 67). Otherwise, if not properly selected, the relevance of an 'imaginary' starting point will remain unclear and will not help our understanding of institutionalisation. This point is particularly important regarding this particular group of countries: to what degree, and in what ways, can the institutional take-offs during, and even before, the communist period be regarded as starting points? Generally, very little attention is paid to the pre-communist tradition or potential starting points at that time: they are no longer regarded as relevant. This is an important message in regard to the state of the profession, although it should be said that this is the case even in the more established communities: the 'relevance 
date' is getting closer and closer. The development of our science has accelerated, and this has not favoured the new entrants.

As for the potential legacy of the communist period, particularly in Poland and Yugoslavia, its evaluation is a controversial issue (Meny, 2010, p. 25). With regard to the starting points, a keener focus on the academic aspects rather than on the institutional ones, together with a deeper analysis, would provide a better understanding of the potential role of the starting momenta. Has this provided a context for the institutionalisation of the profession in some countries that differs from that in others? Previous research has revealed a large variation in the presence of political science during the communist period. At one extreme, possibly the most developed form of political science was to be found in Poland, which had several centres of research that were also well integrated into the international (Western) political science community (Sasinka-Klas, 2010). In Yugoslavia, on the other hand, political science-related institutions served to demonstrate the liberal inclinations of the Tito regime, while their academic output was questionable. The situation was the most meagre in the Soviet Union and, of our country cases, in Romania, Bulgaria, and the Soviet Republics of Moldova, Belarus and the Baltic states. These differences, however, are rarely evaluated in a concrete manner, and even less so from the perspective of the on-going institutionalisation, and the current state, of political science. One rare example is the conclusion reached by Gebethner and Markowski that this well-developed institutional 'past' did not help the take-off of the profession in Poland, and its development was not as visible as in countries where the profession had 'started from scratch' (Gebethner \& Markowski, 2002). Careful attention needs to be paid to the question of whether legacy is an asset or a burden, and most importantly, in either case how legacy has affected the more recent development of political science. Have these potential take-off points lost their significance while new opportunities and constraints exercise a more fundamental impact on the institutionalisation process?

The starting point and the starting conditions both matter not only from the perspective of the past (the potential impact of legacies on institutionalisation patterns and opportunities), but also with regard to certain prospects: what kind of institutional adjustment appeared on offer and feasible at the "starting point"? In the 1990s, the newly democratising countries joined the European profession during a phase in which the main frameworks of political science had already been defined: that is, the main research questions, methodological tools, even structures of 
international cooperation, had been established. In our selected ECE cases, the absence of a previous, lasting academic legacy in the field of political science, together with the rapid pace of democratic transformation, did not offer much room to reflect on, or indeed reconsider, these frameworks. Most actors simply adjusted to the then-dominant themes, schools of thought and methods. As democracy was accepted as a permanent feature of the future landscape, so was political science accepted as a given without having to go back to its fundamentals. The political science communities of the newly democratic countries understandably had not been able to participate in the main formative period of the discipline during the 1960s and 1970s, which were the years that really transformed the profession (Rose, 1990). We could argue in general that this initial situation may have a lasting impact on the formation of political science. Given that the initial institutional decisions made tend to stick (North, 1991), can we then assume that the first patterns of adjustment will also persist? The time dimension potentially matters in the process of institutionalisation not only with regard to momentum (when the new countries joined the political science academia in the more established ones), but also with regard to the speed of institutionalisation, and this is again a specificity of the ECE country group. In the older academic communities, the discipline first developed over a much longer time period. In contrast, in our chosen group of countries, the shortage of time simply added to the difficulties encountered. After its initial formative steps, political science had to face challenges that were either unknown to the countries with a wellestablished political science discipline, or if they did exist then they did not overlap with one another in time, and it was possible to reflect on them subsequently in several stages. For example, in the ECE countries, the enormous increase in student numbers was accompanied by the entry of market forces into the sphere of higher education. The institutionalisation tasks had to be dealt with in a 'compressed period of time': paradoxically, academia faced the free world of opportunities and established patterns and adjustment requirements at one and the same time.

A further particularity is the persistent instability witnessed in most of the countries examined here. Although the proposed theoretical approach aims to be dynamic and incorporate the broad context, and although political science, indeed any science, is never static forever, it is inevitable that in order to establish a degree of institutionalisation of the profession, a certain minimum stability of context is required. On the contrary, however, the evolution of political science in the selected ECE country group 
has been taking place within the context of constant, profound difficulties and, at times, of real crises. The post-transition years were turbulent for all of the countries concerned. A couple of countries went into war in the first years of their new regimes; furthermore, the external world, mainly in the form of EU accession and what this implied in terms of ambitions in higher education, and also what it offered in terms of academic opportunities, represented substantial challenges. Altogether, stability was difficult to achieve in such circumstances. This leads us back to a previous point, namely that in uncertain times we can expect to see mimetic changes in institutional development, as those inside are rarely in a position to make informed decisions, or we can expect to witness external triggers coming from external agents and decision-makers. Is it in any way justifiable to expect to see similar institutionalisation processes and particular outcomes under these conditions, as those witnessed in more established political science communities? The book's comparative chapters, when focussing on these issues, will reflect on the impact of external overload, be this due to a lack of stability or to other local or national characteristics.

The question remains as to whether the institutional development of political science is driven more by the growing internal triggers formed within, and by, the profession, or by inherited triggers, or even by evolving external triggers, and can we expect to see country differences in regard to such? A brief examination of this question already shows that country differences will be as numerous as country similarities. The function and role of the profession, as opposed to those of external triggers, in handling instability will very much depend on the local state of the field when a new crisis (the source of instability), or fresh impetus from external agents, presents a challenge to the discipline. The profession's response may well depend on how far the institutionalisation process has gone, and how deeply the properties in question are embedded. For example, a profession with a stronger identity will be able to force through corrective measures for the sake of the profession, and will be more capable of influencing institutional development in its own interest. On the other hand, a profession that for some reason is later in developing and is lagging behind in the institutionalisation process, will probably handle the recurring challenges increasingly less effectively.

These assumed, and often noted, differences within the country group, lead us to the question of the extent to which we can regard the 
post-communist countries as an entity, and whether it is justified at all to regard those countries' post-communist features as their differentia specifica. Without doubt, in terms of the state of political science, they all shared some common ground, that is, they all re-emerged from a period in which they were governed by a political regime that did not permit the development of political science as such, or only allowed it to exist under substantial constraints. Overall, the communist region had been regarded as a unified entity before its political transformation in 1989-1990, although substantial differences among such countries already existed at that time. The different starting points of the discipline should not be neglected, and the following decades were no less diversified. As Eisfeld and Pal (2010) argue, first 'The variety of transition from communism, different in ideological and institutional consequences, clearly affected the evolving political studies discipline (p. 11) and later the "hybridisation" of these regimes pushed them toward less homogeneity internally', hybridisation meaning diverse departures from the democratisation process or the regimes' democratic credentials. Although eventually they challenge this assumption regarding the possible correlation between democratic departures and political science approaches (p. 15), a decade later we can duly claim that their original viewpoints regarding the differences between countries and the connection between the regimes' political inclinations and political science opportunities, are justified. It remains to be seen how these developments continue to affect political science as an academic discipline. Is politics an influential factor in the institutionalisation opportunities present in ECE? Was there a decisive democratic threshold after all, or are there new thresholds that academia should re-cross? The chapters in the present volume will examine whether the institutionalisation process and the state of the discipline display integrative patterns, or whether divergence prevails. Based on this analysis, their prospects of catching up, integration and becoming a relevant science-which are the issues raised at the beginning of this chapter-will also be examined in a comparative manner.

\section{REFERENCES}

Aarrevaara, T., \& Dobson, I. R. (2013). Movers and Shakers: Do Academics Control Their Own Work? In U. Teichler \& E. A. Höhle (Eds.), The Work Situation of the Academic Profession in Europe: Findings of a Survey in Twelve Countries (pp. 159-181). Springer. https://doi.org/10.1007/978-94-007-5977-0_8 
Becher, T., \& Trowler, P. R. (2001). Academic Tribes and Territories (2nd ed.). SRHE and Open University.

Brady, D. W. (2001). Institutionalisation. In N. J. Smelser \& P. B. Baltes (Eds.), International Encyclopedia of the Social and Behaviorial Sciences (Vol. 11, pp. 7558-7561). Elsevier.

Capano, G., \& Verzichelli, L. (2016). Looking for Eclecticism? Structural and Contextual Factors Underlying Political Science's Relevance Gap: Evidence from the Italian Case. European Political Science, 15(2), 211-232.

DiMaggio, P. J., \& Powell, W. W. (1983). The Iron Cage Revisited: Institutional Isomorphism and Collective Rationality in Organizational Fields. American Sociological Review, 48(2), 147-160.

DiMaggio, P. J., \& Powell, W. W. (1991). Introduction. In W. W. Powell \& P. J. DiMaggio (Eds.), The New Institutionalism in Organizational Analysis (pp. 1-40). Chicago University Press.

Easton, D., Gunnell, J. G., \& Stein, M. B. (1995). Introduction: Democracy as a Regime Type and the Development of Political Science. In D. Easton, J. G. Gunnel, \& M. B. Stein (Eds.), Regime and Discipline. Democracy and the Development of Political Science (pp. 1-26). University of Michigan Press.

Eisenstadt, S. N. (1968). Social Institutions. In D. L. Shills (Ed.), International Encyclopedia of the Social Sciences (Vol. 14, pp. 409-421). The Macmillan Company and The Free Press.

Eisfeld, R., \& Pal, L. A. (2010). Political Science in Central-East Europe and the Impact of Politics: Factors of Diversity-Forces of Convergence. In R. Eisfeld \& L. A. Pal (Eds.), Political Science in Central-East Europe. Diversity and Convergence (pp. 9-36). Barbara Budrich Publishers.

Flinders, M. (2018). The Future of Political Science? The Politics and Management of the Academic Expectations Gap: Evidence from the UK. European Political Science, 17, 587-600. https://doi.org/10.1057/s41304-017-0118-7

Gebethner, S., \& Markowski, R. (2002). Political Science-Poland. In M. Kaase, V. Sparschuh, \& A. Wenninger (Eds.), Three Social Science Disciplines in Central and Eastern Europe: Handbook on Economics, Political Science and Sociology (1989-2001) (pp. 306-321). Informationszentrum Sozialwissenschaften. https://nbn-resolving.org/urn:nbn:de:0168-ssoar-281005

Ghica, L. A. (2014). Academic Bovarism and the Pursuit of Legitimacy: CanonBuilding in Romanian Political Science. European Political Science, 13(2), 171-186.

Hankiss, E. (2002). Brilliant Ideas or Brilliant Errors? Twelve Years of Social Science Research in Eastern Europe. In M. Kaase, V. Sparschuh, \& A. Wenninger (Eds.), Three Social Science Disciplines in Central and Eastern Europe: Handbook on Economics, Political Science and Sociology (1989-2001) (pp. 17-25). GESIS.

Hodgson, G. M. (2006). What Are Institutions? Journal of Economic Issues, $X I(1), 1-25$.

Huntington, S. P. (1965). Political Development and Political Decay. World Politics, $17(3), 386-430$. 
Klingemann, H.-D. (2008). Capacities: Political Science in Europe. West European Politics, 31(1-2), 370-396.

Klingemann, H.-D., Kulesza, E., \& Legutke, A. (eds.) (2002). Political Science in Central and Eastern Europe: The State of the Discipline in the Enlargement Countries of the European Union Ten Years After the Revolution. Berlin: Edition Sigma.

Kwiek, M. (2016). Constructing Universities as Organizations: University Reforms in Poland in Light of Institutional Theory. In E. Samier (Ed.), Ideologies in Educational Administration and Leadership (pp. 193-216). Routledge.

Larson, M. S. (2018). Professions Today: Self-criticism and Reflections for the Future. Sociologia, Problemas e Práticas, 88, 27-42. https://doi.org/10.7458/ SPP20188814796

March, J. G., \& Olsen, J. P. (1984). The New Institutionalism: Organizational Factors in Political Life. The American Political Science Review, 78(3), 734-749.

Meny, Y. (2010). Political Science as a Profession. European Political Science, 9, 11-21. https://doi.org/10.1057/eps.2010.36

North, D. C. (1991). Institutions. Journal of Economic Perspectives, 5(1), 97-112.

Peters, B. G. (1999). Institutional Theory: The "New Institutionalism" in Political Science. Cassells.

Peters, B. G., \& Pierre, J. (1998). Institutions and Time: Problems of Conceptualization and Explanation. Journal of Public Administration Research and Theory, $8(4), 565-583$.

Pierson, P. (2000). The Limits of Design: Explaining Institutional Origin and Change. Governance, 13(4), 475-499.

Pleşu, A. (2002). Financing Difference: Fostering the Social Sciences in the Field of Tension between Homogenization and Differentiation. In M. Kaase, V. Sparschuh, \& A. Wenninger (Eds.), Three Social Science Disciplines in Central and Eastern Europe: Handbook on Economics, Political Science and Sociology (1989-2001) (pp. 12-16). GESIS.

Ricci, D. (1984). The Tragedy of Political Science. Yale University Press.

Rose, R. (1990). Institutionalizing Professional Political Science in Europe: A Dynamic Model. European Journal of Political Research, 18(6), 581-603.

Sasinka-Klas, T. (2010). Political Science in Poland. Roots, Stagnation and Renaissance. In R. Eisfeld \& L. A. Pal (Eds.), Political Science in Central-East Europe. Diversity and Convergence (pp. 207-220). Barbara Budrich Publishers.

Stoker, G., Peters, B. G., \& Pierre, J. (2018). The Relevance of Political Science. In V. Lowndes, D. Marsh, \& G. Stoker (Eds.), Theory and Methods of Political Science (4th ed., pp. 321-332). Palgrave Macmillan.

Weber, M. (1918). Science as a Vocation. In H. H. Gerth \& C. W. Mills (Eds.), Sociology (pp. 134-156). Oxford University Press.

Wilensky, L. H. (1964). The Professionalization of Everyone? American Journal of Sociology, 70(2), 137-158. 
Open Access This chapter is licensed under the terms of the Creative Commons Attribution 4.0 International License (http://creativecommons.org/licenses/ by $/ 4.0 /$ ), which permits use, sharing, adaptation, distribution and reproduction in any medium or format, as long as you give appropriate credit to the original author(s) and the source, provide a link to the Creative Commons licence and indicate if changes were made.

The images or other third party material in this chapter are included in the chapter's Creative Commons licence, unless indicated otherwise in a credit line to the material. If material is not included in the chapter's Creative Commons licence and your intended use is not permitted by statutory regulation or exceeds the permitted use, you will need to obtain permission directly from the copyright holder. 